\title{
DISTRIBUTION AND SIGNIFICANCE OF CANDIDA PRECIPITINS IN SERA FROM PREGNANT WOMEN
}

\author{
Valerie C. Stanley, Rosalinde Hurley and Carthage J. Carroll \\ Bernhard Baron Memorial Research Laboratories, Queen Charlotte's Maternity Hospital, \\ Goldhawk Road, London, W.6
}

NUMEROUS surveys attest to an increased rate of vaginal candidosis and of carriage of Candida albicans during pregnancy (Stough and Blank, 1958; Clarke and Solomons, 1959; Mizuno, 1961). Some 10 per cent. of all patients at Queen Charlotte's Maternity Hospital have clinical evidence of vaginal thrush that can be confirmed by culture of the fungus in the absence of other vaginal pathogens (Hurley and Morris, 1964). Many more have minor degrees of vaginal morbidity that may be causally associated with thrush fungi (Carroll, Stanley and Hurley, 1971; de Fonseka, 1972). More serious infections caused by $C$. albicans and other pathogenic species of Candida occur in obstetric and gynaecological practice, and five fatal cases of systemic candidosis were described by Fox (1971), who reviewed 11 other cases.

Symptomless carriage of $C$. albicans may occur in the vagina, and the fungus cannot be isolated from all clinically typical cases of thrush. A serological test might therefore be of value in the diagnosis of superficial as well as of systemic candidosis. Many serological tests have been devised, including agglutination, complement fixation, and direct and indirect fluorescent antibody staining tests (Winner, 1955; Vogel and Padula, 1958; Kemp and Solotorovsky, 1962; Lehner, 1965, 1966). At present, precipitin tests hold most promise, although until recently a positive result was held to be diagnostic of systemic candidosis, candida granuloma or chronic mucocutaneous candidosis. Doubt is cast on this by the occasional presence of candida precipitins in the sera of healthy persons (Chew and Theus, 1967; Pepys et al., 1968) and by their fairly frequent presence in the sera of patients undergoing cardiac surgery who did not develop systemic candidosis (Murray, Buckley and Turner, 1969).

We now describe the distribution of candida precipitins in the sera of 303 pregnant women and comment on the probable significance of their presence.

\section{MATERIALS AND METHODS}

\section{Preparation of antigens}

Three antigens derived from a strain of Candida albicans, group A (London School of Hygiene and Tropical Medicine no. 3153), were produced in bulk to minimise batch variation and stored in the freeze-dried state.

(a) Mickle-disintegrated cytoplasmic antigen. A modification of the methods of Stallybrass (1964) and Taschdjian et al. (1964a) was used. The fungus was grown in shaken culture at $37^{\circ} \mathrm{C}$ for $48 \mathrm{hr}$. The culture medium was modified Sabouraud's glucose broth (peptone

Received 27 Oct. 1971; accepted 1 Jan. 1972.

J. MED. MICROBIOL.-VOL. 5 (1972) 
1 per cent., glucose 2 per cent., $p \mathrm{H}$ 6.8) dispensed in $2 \cdot 5-1$ portions in 5 -1 flasks. The washed yeast was suspended in 0.85 per cent. $\mathrm{NaCl}$ (" saline ") to give a packed-cell volume of 40 per cent. An equal volume of $\frac{1}{16}$-in. $(1 \cdot 6-\mathrm{mm})$ glass beads was added and the mixture was shaken for $20 \mathrm{~min}$. on a Mickle shaker. The contents of the tubes were resuspended in $5 \mathrm{ml}$ saline and centrifuged at 3000 r.p.m. to remove the glass beads and intact cells. The supernatant was stored overnight at $-20^{\circ} \mathrm{C}$, thawed and finally centrifuged at $35,000 \mathrm{~g}$. The opalescent supernatant was freeze-dried.

(b) Mannan antigen. The fungus was cultured in the same medium as was described previously. Mannan was extracted by autoclaving whole yeast cells from a 24 -hr culture in

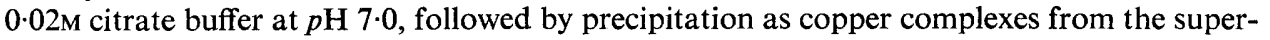
natant, according to the method of Peat, Whelan and Edwards (1961) as modified by Faux (1968).

(c) Culture-filtrate antigen. The fungus was cultured in the same medium for 7 days. The centrifuged supernatant was Seitz-filtered, dialysed and freeze-dried.

\section{Reconstitution of antigens}

The antigens were reconstituted in borax-boric acid buffer at $p \mathrm{H} 8.6$ (boric acid $6.7 \mathrm{~g}$ and sodium borate decahydrate $13.4 \mathrm{~g}$ per 1 of distilled water); see below for concentrations.

\section{Titration of antigens}

Each antigen was titrated against (i) sera from rabbits hyperimmunised to the homologous strain of $C$. albicans by subcutaneous injection of Mickle-disintegrated antigen that had not been subjected to the final high-speed centrifugation; (ii) human positive sera selected from pilot studies (de Fonseka); and (iii) sera from cases of systemic candidosis kindly supplied by Dr Helen Buckley. The concentrations selected for use were, for cytoplasmic antigen, $40 \mathrm{mg}$ per $\mathrm{ml}$, for mannan antigen, $1 \mathrm{mg}$ per $\mathrm{ml}$, and for culture-filtrate antigen, $40 \mathrm{mg}$ per $\mathrm{ml}$.

\section{Demonstration of precipitins}

Double-diffusion tests were carried out in 1.5 per cent. Oxoid Ionagar no. 2 containing 0.1 per cent. sodium azide as preservative, buffered to $p \mathrm{H} 8.6$ with the borate buffer described above, and layered at a depth of $1.5 \mathrm{~mm}$ in Guthrie test trays (Mast Laboratories, Ltd, Liverpool). A pattern of wells, designed to conserve antigen, was cut to give serum wells

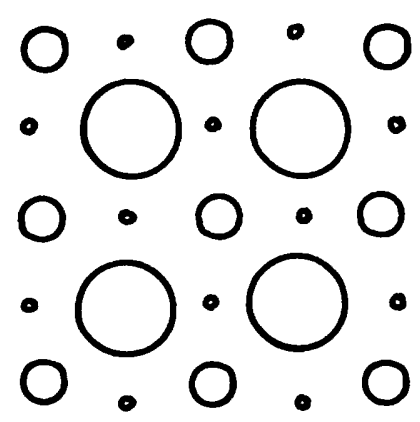

FigurE.-Diagram of well pattern for double diffusion. Nine such patterns were punched per plate.

$14 \mathrm{~mm}$ in diameter surrounded by antigen wells of $6 \mathrm{~mm}$ and $2 \mathrm{~mm}$ diameter, each separated from the serum well by a distance of $6 \mathrm{~mm}$. The smaller antigen wells were designed to give a volume ratio about one-tenth of that of the large wells, in order to detect weakly reacting sera (Murray et al.) or reactions that might be masked by antigen excess (Pepys et al.).

The plates were incubated at $30^{\circ} \mathrm{C}$ for 5 days. The agar was removed in sections, washed for 3 days in saline containing azide, and dried at $37^{\circ} \mathrm{C}$ between filter-paper (Whatman no. 3). 
For final recording of results, the dried agar was stained with 0.2 per cent. Ponceau $S$ dissolved in 3 per cent. acetic acid, and differentiated in the same solvent.

\section{Source of sera}

We collected sera from 318 pregnant women who were seen consecutively on their first visit to the booking clinic. All the sera were stored at $-20^{\circ} \mathrm{C}$. The patients were unselected, but 15 were subsequently excluded from the investigation because the information about them was incomplete. Each patient was examined carefully by the same observer (C. J. C.) and the clinical findings, including relevant past history and history of treatment for vulvovaginitis, were recorded. At the same time, a warm saline swab was collected for examination for trichomonads, and a dry swab, taken from the middle third of the lateral vaginal wall, was used for microscopy and culture for fungi. Yeasts were identified according to the criteria of Lodder and Kreger-van Rij (1952).

\section{RESULTS}

Details of the clinical findings and of their relationship to the isolation of pathogens will be described elsewhere (Carroll, Stanley and Hurley, unpublished). Briefly, 27 of 303 patients ( 9 per cent.) had clinical thrush that was regarded as typical by the examining obstetrician; 15 of these had thrush plaques, and the remainder, with two exceptions, had discharge, pruritus, vulvitis and vaginitis; the exceptional cases had a history of recurrent discharge and vulvovaginitis, worsening during pregnancy and treated with anti-fungal antibiotics. None of these patients had Trichomonas vaginalis present in wet films, nor had metronidazole been given.

A further 64 were regarded, from clinical evidence, as probable cases of mycotic vulvovaginitis, bringing the total of typical and probable vaginal thrush to 91 (30 per cent.). Typical or probable thrush was defined according to one or all of the following criteria: presence of thrush plaques (lard-like patches) or of white flakes in the discharge; pruritus accompanying discharge, if not associated with $T$. vaginalis, and provided metronidazole had not been given; symptoms and signs of vulvovaginitis at the time of examination combined with recent or current treatment with nystatin or any other antifungal preparation; firm opinion of the examining obstetrician (C. J. C.).

Of the remaining 212 women, 113 had various signs and symptoms that were considered not to be attributable to mycotic infection. The "healthy" pregnant women (99) did not have vulvovaginitis, cervicitis or heavy discharge at the time of examination; 58 had no discernible discharge and 41 had a slight odourless, colourless discharge. None of the women was scrutinised for forms of candidosis other than of the vagina.

Candida precipitins were detected in the sera of 56 of the 303 women (18 per cent.). Precipitins to all three antigens occurred in 17 sera (6 per cent.), to two antigens in five sera ( 2 per cent.) and to a single antigen in 34 sera (11 per cent.): the responses to a single antigen were to culture filtrate only in 20 sera ( 7 per cent.) and to mannan only in 14 sera ( 5 per cent.). In no case was there precipitation only with the cytoplasmic antigen. Precipitin bands were of either the " $\mathrm{H}$ " or the " $\mathrm{R}$ " type (Pepys et al.) and were sometimes multiple. The most frequent response was to culture-filtrate antigen (39 cases, 13 per cent.); precipitins to the mannan antigen were observed next most frequently 
(36 cases, 12 per cent.); and precipitins to the cytoplasmic antigen were observed least frequently ( 20 cases, 7 per cent.). In order to detect all positive reactions it was necessary to use the antigens at both high and low concentrations (table I).

TABLE I

Precipitins to three antigens of Candida albicans, group $A$, each tested at two different concentrations, in 56 "positive" sera*

\begin{tabular}{l|c|c|c}
\hline \multirow{2}{*}{ Antigen concentration } & \multicolumn{2}{|c}{$\begin{array}{c}\text { Number of positive reactions obtained, } \\
\text { at the concentrations shown, with }\end{array}$} \\
\cline { 2 - 4 } & $\begin{array}{c}\text { mannan } \\
\text { antigen }\end{array}$ & $\begin{array}{c}\text { cytoplasmic } \\
\text { antigen }\end{array}$ & $\begin{array}{c}\text { culture-filtrate } \\
\text { antigen }\end{array}$ \\
\hline $\begin{array}{l}\text { High concentration only } \\
\text { Bow concentration only }\end{array}$ & 1 & 0 & 24 \\
Eoth concentrations & 14 & 3 & 4 \\
\hline Either or both concentrations & 36 & 20 & 39 \\
\hline
\end{tabular}

* Of 303 tested. A " positive" serum was one that gave a precipitin reaction with one or more of the antigens.

TABLE II

Relationship between presence of precipitins* to Candida albicans and vaginal health or morbidity

\begin{tabular}{l|c|c}
\hline \multicolumn{1}{c|}{ Category of patients } & $\begin{array}{c}\text { Number of sera from the stated } \\
\text { category of patients }\end{array}$ \\
\cline { 2 - 3 } & examined & $\begin{array}{c}\text { in which precipitins } \\
\text { were found }\end{array}$ \\
\hline $\begin{array}{l}\text { Healthy } \\
\text { Typical thrush }\end{array}$ & 99 & $\begin{array}{r}13(13) \dagger \\
9(33)\end{array}$ \\
$\begin{array}{l}\text { Probable thrush } \\
\text { Discharge, probably not mycotic }\end{array}$ & $\begin{array}{r}27 \\
94\end{array}$ & $\begin{array}{r}12(13) \\
1(5)\end{array}$ \\
Other signs or symptoms & 21 & $56(18)$ \\
\hline \multicolumn{1}{c|}{ All } & 303 & 56 \\
\hline
\end{tabular}

* To one or more or the three antigens.

$\dagger$ In parentheses: percentage with precipitins.

Table II shows that the distribution of precipitins throughout the population studied is not uniform. There is a statistically highly significant variation of the presence of precipitins to one or more of the antigens with different degrees of vaginal health or morbidity $\left(\chi^{2}=15 \cdot 7, \nu=4, \mathrm{P}<0.01\right)$. Precipitins occurred in 33 per cent. of the 91 women with typical or probable mycotic vulvovaginitis, and in only 26 ( 12 per cent.) of the remainder of the population studied, which is also statistically significant $(\mathrm{P}<0.001)$. Also, precipitins appeared more frequently in patients with typical or probable thrush than in the "healthy" 
population $(\mathrm{P}<0.01)$, or in patients with vaginal morbidity that was probably not mycotic $(\mathrm{P}<0.001)$.

There is a strong correlation between the demonstration of precipitins and vaginal morbidity; 43 of the 56 precipitin-positive women studied ( 77 per cent.) had signs or symptoms of vulvovaginitis or cervicitis when examined; $30 \mathrm{had}$ thrush as defined, six had cervicitis, one had vulvovaginitis and six had a heavy discharge. The most frequent symptom was discharge, which was present in 70 per cent. of the precipitin-positive women; this was heavy, offensive or coloured in about two-thirds of cases, and light in the remainder.

TABLE III

Occurrence of precipitins to three antigenic preparations of Candida albicans in various categories of patient

\begin{tabular}{|c|c|c|c|c|}
\hline \multirow{3}{*}{ Category of patients } & \multicolumn{4}{|c|}{ Number of sera, from the stated category of patient, that } \\
\hline & \multirow{2}{*}{$\begin{array}{c}\text { were } \\
\text { examined }\end{array}$} & \multicolumn{3}{|c|}{ showed precipitins to } \\
\hline & & $\underset{\text { antigen }}{\operatorname{mannan}}$ & $\begin{array}{l}\text { cytoplasmic } \\
\text { antigen }\end{array}$ & $\begin{array}{l}\text { culture-filtrate } \\
\text { antigen }\end{array}$ \\
\hline $\begin{array}{l}\text { 1. Typical or probable vaginal } \\
\text { thrush }\end{array}$ & 91 & $18(20)^{*}$ & $11(12)$ & $20(22)$ \\
\hline $\begin{array}{l}\text { 2. All other } \\
\text { (a) Signs or symptoms (or } \\
\text { both) but probably not } \\
\text { mycotic } \\
\text { (b) Healthy }\end{array}$ & $\begin{array}{rr}212 & 113 \\
& \\
& 99\end{array}$ & $\begin{array}{lll}18 \quad(8) & \\
& & 10(9)\end{array}$ & $\begin{array}{lll}9 & (4) & 5(4)\end{array}$ & $\begin{array}{r}9(8) \\
10(10)\end{array}$ \\
\hline Total & 303 & $36(12)$ & $20(7)$ & $39(13)$ \\
\hline
\end{tabular}

* In parentheses: percentage showing precipitins.

The association between mycotic vulvovaginitis and the presence of precipitins to the three antigens is recorded in table III. With each antigen, a significantly higher proportion of sera from women with typical or probable thrush, as defined, than of sera from the remainder of the population $(\mathrm{P}<0.01)$ contained precipitins. Separate comparisons of the frequency of a positive reaction in women suffering from typical or probable thrush with its frequency in " healthy " women, or in women with other sorts of vaginal morbidity, also showed a statistically significant difference.

The relationship between the demonstration of precipitins and the isolation of C. albicans from the vagina is statistically significant (table IV). Precipitins are more likely to occur in patients from whom C. albicans was isolated ( 15 of $50 ; 30$ per cent.) than in those whose vaginal swabs did not yield the pathogen (41 of $253 ; 16$ per cent.).

C. albicans was isolated from 15 of 56 (27 per cent.) patients with precipitins; six of these patients had typical thrush, and eight had probable thrush. 
Thus 14 of the 15 women (93 per cent.) from whom C. albicans was isolated in the presence of a positive serological result had mycotic vulvovaginitis as diagnosed on clinical criteria. However, 85 per cent. ( 77 of 91 ) of those with mycotic vulvovaginitis so defined did not give a positive result in both the cultural and the serological test.

TABLE IV

Relationship between isolation of C. albicans from the vagina and demonstration of precipitins in the serum of the same patient

\begin{tabular}{l|c|c|c}
\hline \multicolumn{1}{c|}{ Vaginal swab } & \multicolumn{3}{|c}{ Number of sera } \\
\cline { 2 - 3 } & $\begin{array}{c}\text { showing } \\
\text { precipitins }\end{array}$ & $\begin{array}{c}\text { showing no } \\
\text { precipitins }\end{array}$ & examined \\
\hline $\begin{array}{l}\text { C. albicans } \text { not isolated } \\
\text {. albicans } \text { isolated }\end{array}$ & $\begin{array}{l}41 \\
15\end{array}$ & $\begin{array}{r}212 \\
35\end{array}$ & $\begin{array}{r}253 \\
50\end{array}$ \\
\hline Examined & 56 & 247 & 303 \\
\hline & $\chi^{2}=4 \cdot 25 ; \mathrm{P}<0.05$.
\end{tabular}

\section{Discussion}

Early work suggested that precipitating antibodies to Candida albicans occurred only in systemic or deep-seated candidosis. Stallybrass (1964), who investigated 834 human sera, including 215 from pregnant women, with five different preparations of antigen, found precipitins only in the serum of a single patient with systemic candidosis, but it is not clear whether all preparations were tested against all sera. Workers who used as antigen material obtained by sonic disintegration of C. albicans (Taschdjian et al., 1964a and b, 1967; Newcomer et al., 1966; Louria et al., 1967) demonstrated precipitins in the sera of patients with systemic candidosis, candida granuloma and chronic superficial candidosis associated with autoimmune endocrinopathies but not in the sera of healthy persons or in those with uncomplicated muco-cutaneous candidosis. Reactions to oidiomycin (Hollister-Stier Laboratories, Philadelphia, Pa.), a commercial culture filtrate antigen, in five of 43 sera from patients with superficial candidosis were discounted as false positives (Taschdjian et al., 1967).

Chew and Theus (1967) demonstrated precipitins to the mannan antigen in unconcentrated sera of healthy adults and of patients with muco-cutaneous candidosis. Pepys et al. (1968) obtained carbohydrate- and protein-type reactions to mannan and culture-filtrate antigens with the unconcentrated sera of asthmatics, with or without pulmonary eosinophilia, and in healthy subjects. Murray et al. (1969), who used a cytoplasmic antigen, examined the sera of patients who had had open operations on the heart. They were able to demonstrate precipitins to several species of Candida in sera not only from patients with candida endocarditis but also from other patients who gave no evidence of 
deep-seated candidosis. According to Buckley (1971), the precipitins in the sera of the patients without deep-seated candidosis were directed against the mannan component of the extract. Both Chew and Theus, and Pepys et al., comment that cytoplasmic antigens contain mannan, and Pepys et al. attributed reports that precipitins are found only in subjects with deep-seated candidosis to an antigen-antibody imbalance in the test system. Our results also show that low concentrations of the three antigens will detect weak reactions in the sera of pregnant women.

Differences in the sensitivity of the test method, in the type and concentration of the antigen used, and in the composition of the population studied, may explain the divergent results reported in the literature. The manner of preparation of antigens used in our studies approximate to those used by others. The antigens were standardised against appropriate sera and used at what appeared to be optimum concentrations, but they are not defined chemically.

We know of no other investigation into the occurrence of candida precipitins in the sera of pregnant women. Our results show a significant association between the presence of precipitating antibodies to C. albicans and (1) the isolation of the fungus from the vagina and (2) clinical evidence of mycotic vulvovaginitis. Statistical analysis of the serological response to each antigen independently, or to any one of the three antigens used, shows that precipitating antibodies occurred more frequently in patients with vaginal thrush than in the remainder of the population. The possibility that the "false positive " reactors in this study had other forms of candidosis were carriers of Candida elsewhere in the body, or were allergic to Candida was not investigated.

The presence of precipitins in pregnancy thrush may be related to the chronicity of the infection. Forty-three per cent. of women who had precipitins in their serum gave a history of recurrent or refractory candida vulvovaginitis, compared with 19 per cent. of those without precipitins.

Precipitins were not detected in the sera of all women with mycotic vulvovaginitis, and candida was not always isolated from the single specimen taken from the vagina of women with thrush in pregnancy. However, our findings suggest that the isolation of $C$. albicans from the vagina, combined with demonstration of candida precipitins in the serum, is virtually diagnostic of candida vulvovaginitis in pregnant women. We suggest that serological tests may be useful in distinguishing candida carriage from candida sepsis at other body sites.

\section{SUMMARY}

Sera from 303 pregnant women were examined for antibodies to Candida by means of a precipitin test in gel. Three preparations derived from C. albicans, type A (mannan antigen, cytoplasmic antigen and culture-filtrate antigen), were used, each at two concentrations.

Precipitins to all three antigens were found more frequently in the sera of women with mycotic vulvovaginitis than of other women. When serum precipitins were present and $C$. albicans was isolated from the vagina there was nearly always clinical evidence of vaginal thrush. 
We thank the Department of Health and Social Security for sponsoring part of this work, and our clinical colleagues at Queen Charlotte's Maternity Hospital for allc wing one of us to examine their patients.

\section{REFERENCES}

Buckley, Helen R. 1971. Personal communication.

Chew, W. H., AND Theus, T. L. 1967. Candida precipitins. J. Immun., 98, 220.

ClARKE, D. H., AND Solomons, E. 1959. An evaluation of routine culture examinations for Trichomonas vaginalis and Candida. Amer. J. Obstet. Gynec., 78, 1314.

FAUX, JeNNIFER, A. 1968. Immunological studies of the antigens of Candida albicans. Ph.D. Thesis, Univ. of London.

De Fonsexa, C. Ivy 1972. The distribution of Candida species and their antibodies in pregnant women and the newborn, a clinical and experimental study. Ph.D. Thesis. Univ. of London.

Fox, L. P. 1971. Fatal superinfection with monilia in gynecological surgery. Amer. J. Obstet. Gynec., 110, 285.

Hurley, Rosalinde, AND Morris, E. D. 1964. The pathogenicity of Candida species in the human vagina. J. Obstet. Gynaec. Br. Commonw., 71, 692.

KemP, G., AND Solotorovsky, M. 1962. Fluorescent antibody studies of pathogenesis in experimental Candida albicans infections of mice. J. Immun., 88, 777.

LEHNER, T. 1965. Immunofluorescent investigation of Candida albicans antibodies in human saliva. Archs Oral Biol., 10, 975.

LEHNER, T. 1966. Immunofluorescence study of Candida albicans in candidiasis, carriers and controls. J. Path. Bact., 91, 97.

LODDER, JACOMINA, AND KREGer-VAN RiJ, N. K. W. 1952. The yeasts: A taxonomic study. North Holland Publishing Co.

Louria, D. B., Shannon, D., Johnson, G., Caroline, Leona, Okas, A., and Taschditan, ClaIRE L. 1967. The susceptibility to moniliasis in children with endocrine hypofunction. Trans. Assoc. Amer. Physns., 80, 236.

Mrzuno, S. 1961. Vulvovaginal candidiasis: survey of vulvovaginal candidiasis in Japan. In Studies on candidiasis in Japan, p. 19. Research Committee of Candidiasis, Education Ministry of Japan, Tokyo.

Murray, I. G., Buckley, Helen R., and Turner, G. C. 1969. Serological evidence of candida infection after open-heart surgery. J. Med. Microbiol., 2, 463.

Newcomer, V. D., Landau, J. W., Lehman, R., Dabrowa, Nina, and Fujiwara, A. 1966. candida granuloma; studies of host-parasite relationships. Archs Derm., 93, 149.

Peat, S., Whelan, W. J., AND Edwards, T. E. 1961. Polysaccharides of bakers' yeast. Part IV. Mannan. J. Chem. Soc., 1, 29.

Pepys, J., Faux, Jennifer A., Longbottom, Joan L., McCarthy, D. S., and Hargreave, F. E. 1968. Candida albicans precipitins in respiratory disease in man. J. Allergy, 41, 305.

Stallybrass, F. C. 1964 . Candida precipitins. J. Path. Bact., 87, 89.

Stough, W. V., AND BlaNk, H. 1958. Vaginal candidiasis in South Florida. Obstet. Gynec., N.Y., $12,338$.

Taschdian, Claire L., Dobkin, G. B., Caroline, Leona, and Kozinn, P. J. 1964a. Immune studies relating to candidiasis. II. Experimental and preliminary clinical studies on antibody formation in systemic candidiasis. Sabouraudia, 3, 129.

Taschdian, Clatre L., Kozinn, P. J., AND Caroline, Leona 1964b. Immune studies in candidiasis. III. Precipitating antibodies in systemic candidiasis. Sabouraudia, 3, 312.

Taschdian, Claire L., Kozinn, P. J., OKas, A., Caroline, leona, and Halle, M. A. 1967. Serodiagnosis of systemic candidiasis. J. Infect. Dis., 117, 180.

Vogel, R. A., AND PAdulA, J. F. 1958. Indirect staining with fluorescent antibody for detection of antibodies to pathogenic fungi. Proc. Soc. Exp. Biol. Med., 98, 135.

WINNER, H. I. 1955. A study of Candida albicans agglutinins in human sera. J. Hyg., Camb., 53, 509. 